\title{
MASS MEDIA AND ENGLISH LEARNING ACTIVITY IN BLITAR INDONESIA
}

\begin{tabular}{c} 
Abdul Aziz \\
\\
\hline aziz@bsi.uin-malang.ac.id \\
Fakultas Humaniora \\
Universitas Islam Negeri Maulana Malik Ibrahim Malang \\
Jl. Gajayana 50 Malang \\
\hline
\end{tabular}

\begin{abstract}
This study is intended to know how English teachers in MTsN Selorejo, Blitar employ variety of English learning sources and implement English learning activity relevant to student's learning preference in order to create joyful and conducive atmosphere of English learning activity to achieve the learning target better. The researcher uses qualitative method to conduct the study. The researcher analyzes the qualitative data from interview and observation in order to describe the phenomena. The findings show that the teachers use variety of English learning sources to enrich English learning materials that are easily to access and familiar to the students. The teachers use the materials from mass media like English corner and English program by radio, television, magazine, and newspaper to facilitate students to improve their English proficiency. The teachers design English learning activity relevant to student's learning preference and talent based on materials from mass media. It makes students more motivated to learn English and easy to achieve the learning target.
\end{abstract}

Keywords: mass media, English learning activity

\section{INTRODUCTION}

We know that the position of teacher is decisive in English learning activity within the school. Teacher plays an important role to facilitate the learners learn English better by designing teaching activity that is relevant to the local context and defining the material that is appropriate to students' level of English learning. Teacher is able to use students' experience, local context, and school environment as the English learning resources to create conducive atmosphere and joyful situation in English learning activity. Teacher should be concerned with student's capacity, student's level in English learning, and student's preference of English learning strategy in order to conduct teaching-learning activity well. In this case, the teacher should realize that each student has each potential and has his own way to understand the material well and improve their skill in English. Some students are good at oral fluency and other students are better to understand the written text of English.

Rubin and Thompson (1982) say that good language learner determines his own way to achieve better target in language learning and master language skills (Brown, 2000). Then, Rogers (1983) says that teacher is a facilitator, it means that should create the learning context that enables students learn the language (Brown, 2000). In light of this, Rogers (1983) states that teacher should facilitate the students determine his won best way for language learning, value and respect student's talent and potential, and communicate openly and empathetically with students (Brown, 2000). In fact, there are some students that are good at auditory and visual activities. Then, other students are good at oral activity. The next, there are also some students that are good at kinesthetic or motor activities (Nasution, 1986). 
In this modern era, the students are able to acquire some information of English learning and advance their knowledge of English through variety of sources. They can use computer assisted program, radio, newspaper, television, and other sophisticated gadget to improve their mastery of English. In light of this, teacher is able to use mass media to enrich their teaching material in English learning activity. Teacher doesn't solely rely on English textbook, but he has big latitude to develop teaching material and design learning activity using variety of learning sources. Ki Hajar Dewantara says that school, family, and society are the centre of education. Schramm (1984), Rymes (2008), and Tavani (2009) say that mass media has an important role to advance the knowledge, change one's mind, discuss social problem, and as a means of education. Biagy (1996) described that mass media provides a lot of chances for language practice to the students (Tavani, 2009). Then, Astrid S. Susanto (1976) says that mass media functions to give information, entertainment, persuasion, and education. This study is intended to explore how teacher employs variety of sources in English learning activity and implements teaching-learning activity of English that is relevant to each student's talent and preference to improve their motivation and achievement of English learning in MTsN Selorejo, Blitar.

\section{Review of Literature}

The Indonesian government already defines curriculum 2006 as the guideline of teaching-learning activity within formal education institution throughout Indonesia. In English learning activity, curriculum 2006 continues curriculum 1994 to use communicative approach in English teaching. It is an approach to foreign language teaching that the goal of language learning is communicative competence (Richards et al,1997). According to curriculum 2006, the students have to master four language skills to communicate in English at certain literacy level. Literacy level includes performance, functional, informational, and epistemic level. Performance level means the students are able to apply the language in four language skills such as listening, speaking, reading, and writing. Functional level means the students are able to use English for daily necessity like reading newspaper, hint, manual, and so forth. Informational level means the students are able to use English to access information, knowledge and technology. Epistemic level means the students are able to use English to transfer knowledge and technology. Curriculum 2006 suggests contextual learning and task or activity based learning as learning method to conduct English activity in school. In curriculum 2006, these methods are called language accompanying action and here-andnow method. Contextual learning means learning activity should be related to students' experience and school or classroom environment.

Further, the Minister of National Education in the era of President Susilo Bambang Yudhoyono defined curriculum 2013 as the guideline in learning activity of Indonesian educational institution. Curriculum 2013 proposed theme-based learning as the approach to manage learning activity for the students (Hamid Hasan, 2015). It means that the teacher designs the learning material according to the theme such as family, sport, environment and so forth. However, curriculum 2013 isn't appropriate to be implemented to all levels of schooling (Hamid Hasan, 2015). It is effective to implement curriculum 2013 for the pupils in the early years of schooling in which the pupils have to know their environment, develop their language skill, develop physical and mental aspect, and socialize with others (Hamid Hasan, 2015). In this case, curriculum 2013 is in line with their developmental stage. On another side, it isn't easy to apply curriculum 2013 to the pupils in the upper level of schooling in which they have to understand the more complex and specific learning materials such as the theory of Archimedes or the theory of Kierchoff in Physics, the concept of integral and differential in Mathematics and so forth. Unfortunately, Anies Baswedan as the new Minister of Education and Culture once stopped curriculum 2013 as the guideline of learning activity in Indonesian schools and implemented curriculum 2006 in Indonesian schools again (Kompas, December 8, 2014). Afterwards, in the academic year of 2015 Anies Baswedan activated curriculum 2013 again as the guideline to manage learning activity in Indonesian schools. However, now 
curriculum 2013 is still on trial for around 6200 schools throughout Indonesia. So far, most of Indonesian schools still use curriculum 2006 to manage learning activity to the students.

In fact, both curriculum 2006 and curriculum 2013 determined communicative approach and contextual learning method to manage English learning activity to the students. It means that the students have to master English as means of communication and to develop their knowledge using the learning material related to their everyday life. Then, the design of English learning activity in both curriculum 2006 and curriculum 2013 are in line with theme-based learning and task-based learning approach. McIntosh (1971) says that students are easy to understand the material that discusses about the people they can identify and the context that they are familiar with (Katayama, Matsuhata, Douta, Fujii, 1985). Task based learning means a learning activity which is organized around tasks such as telephone conversation, drawing a picture, cooking traditional food and others (Richards et al,1997). Cameron (2001) proposes themebased learning and task-based learning to design language learning activity. Themebased learning and task-based learning are interconnected and helpful to manage communicative activity of language learning. These approaches are useful to facilitate the students to use English during the English class. Theme like family, occupation, food, sport is developed through some activities during English class. For example when the teacher chooses Indonesian society as a topic of language learning; he can arrange some activities of English learning for the students like cooking Indonesian food, playing traditional games of Indonesia and the like. The teacher must be concerned with classroom management to do teaching process using theme-based learning and task-based learning so that English activity runs effectively.

However, Language learning problems don't end in the matter of how to teach or how to learn but we have to be concerned with the matter of determining the learning material that facilitates the better language learning activity of students (Littlewood, 1981). He underlies that language learning is related to the existence of language learner inside and outside the classroom. To develop English learning material for the students who encounter English easily outside the classroom is different from to develop learning material for the students who are limited to encounter English outside the classroom. Littlewood says that language learning must be intentionally structured to give adequate exposure to the language and keep students' motivation. Language learning or teaching has to make sense to the students (Cameron,2001). Language teaching plan must be practical and facilitates the language learning of students. Cameron emphasizes that teaching can never guarantee learning, it just constructs opportunities for learning to help the learners take advantage of them. How to teach and what to teach are the most concerned problems of language learning process.

Related to the statements above, English teacher must be creative to develop teaching material and doesn't solely rely on English textbook to conduct teaching activity to give more opportunity to the students to encounter English inside and outside classroom. McIntosh (1971) says that teacher should go beyond textbook to manage teaching-learning activity within the classroom so that students are able to broaden their horizon (Katayama et al, 1985). Nowadays, students easily encounter mass media and sophisticated gadget in their daily life. This situation actually facilitates English teacher develop the learning material and design learning activity using variety of language learning material from mass media. Schramm (1984) says that the students mostly spend the time to learn at home, and they are able to enrich the information of school subjects through mass media. Tavani (2009) and Rymes (2008) state that mass media provides a lot of chances to practice the language, facilitates the students to develop the language skills, and motivate them to learn the language. Then, Supeno (1976) says that some activities like reading magazine and newspaper, listening to the radio, and watching television can be the way for students to study the learning material. Tondowidjojo (1985) says that mass media gives the way to people especially students to have clear thinking, good analysis, and free and critical thinking. Mass media provides 
some materials for the students to do learning activities like oral activity, audio-visual activity, writing activity, and kinesthetic activity. Mass media provides contextual learning materials in which the students can learn about history, geography, literature, social life and so forth (Tavani, 2009). The next, Paul Sunderson (2002) described that to learn the interesting new things in mass media undoubtedly improved motivation of the students to learn the language (Tavani, 2009). In light of this, English teacher is able to develop teaching material using the material of mass media and design teaching activity in line with students' preference and potential in order to make the students more motivated and easier to learn the language.

Tavani (2009) described that students are able to practice short conversation, discussion, expressing idea, asking question, interview, and telling story in oral activity using the materials from mass media. Further, Tavani (2009) says that mass media like newspaper, magazine, radio, and television provides language learning material for activity inside and outside classroom. Walsh et al (1967) say that in speaking activity the students are able to practice speaking English with reasonable fluency and correctness in pronunciation; the students practice describing historical and current events, retelling story, discussing social problem and so forth (Katayama et al, 1985). Then, audiovisual activity provides the chance to students to practice reading and listening activity (Nasution, 1986). Reading is the main activity to for the learners to improve their knowledge in English especially for those whose mother tongue isn't English. The Liang Gie (1987) says that no learning activity without reading activity. English learners mostly improve their knowledge of English such as vocabulary improvement through reading activity. Walsh et al (1967) say that reading activity gives big opportunity for the students to improve their skill in reading English text without conscious translation; they practice reading English text about short story, history, geography and others (Katayama et al, 1985). Listening activity includes listening to conversation, discussion, music, speech and so forth (Nasution, 1986). Tondowidjojo (1986) says that listening activity can be done through listening to the program of mass media to understand the material of the program. Walsh et al (1967) say that listening activity is done to improve students' skill to understand English words spoken by native speaker; students practice listening to short English news, short drama, and others (Katayama et al, 1985). Further, Huebener (1967) describes that audio-visual aids in English teachinglearning activity has some advantages as follows:

1. Reduce the danger of verbalism.

2. Increase better understanding.

3. Arouse interest in research.

4. Develop power of oral and written communication.

5. Encourage pupil participation.

6. Build up clearer and richer concepts.

7. Provide for group thinking and planning

8. Train in efficient work and study habits.

9. Instill favorable attitudes.

10. Foster the appreciation of beauty.

(Katayama et al, 1985:99)

The next, Nasution (1986) describes that writing activity gives the way to students to practice writing a composition, summarizing, short story, and so forth. Walsh et al (1967) say that in writing activity the students are able to write description, report, and informal letter with clarity and correctness; the students also practice writing a composition dealing with their own experiences and topics that are interesting for them (Katayama et al, 1985). Aside from that, the students also are able to make clipping for the material they are interested in from magazine and newspaper. Clipping is a clipped item out of newspaper and magazine (Hornby, 1989). The students usually display the clipping material in school magazine. Clipping material provides present and interesting English learning material for the students. This activity stimulates the students to be creative and updated to select the current interesting and useful English learning material from mass media.

\section{Research Objective}

The research is intended to know how English teacher employs variety of sources in English Learning activity and implements English teaching-learning activity that is relevant to each student's talent and preference to improve students' motivation 
and achievement of English learning in MTsN Selorejo, Blitar.

\section{METHOD}

The study employs qualitative method. It is the descriptive qualitative study. The researcher conducts non experimental study to study the phenomena and develop knowledge based on ideas, theories, and data of research. Libarkin and Kurdziel (2002) state that qualitative method is considered as an unconstrained approach to study phenomena; while quantitative method deals with identified problem, based on testing a theory, measured with numbers, and analyzed using statistical techniques (Creswell, 2003). Then, Dash (2005) explains that qualitative method allow the researcher to develop knowledge using observation, experiment, generalization, and interpreting the phenomena based on the researcher' own experience and knowledge. Wiersma (2000) says that qualitative study has its origin in descriptive analysis, and is essentially and inductive process, reasoning from the specific situation to a general conclusion. The next, qualitative researcher has great concerns for the impact of the process, typically more than quantitative researcher (Wiersma, 2000).

The study uses population to determine the sample of the study. In light of this, the researcher determines all English teachers in MTsN Selorejo, Blitar as the respondents of the study to gain the data of the research. The qualitative data of the research are gain through unstructured interview with English teachers. Patton (1990), and Burgess (1993) that interview has some advantages to undestand the problems better (Cheah Lee Hwa, 2008). Firstly, it allows the researcher to understand the participants' past experience, current living situation, and projection of future life. Secondly, interview is flexible and deep so that the rearcher can get the richer data of research. Thirdly, the researcher can obtain significant information since the participant can express the idea openly. Koul (1984) says that the focused interview aims at some particular event or experience rather than general lines of inquiry about the event, and the non-directive interview gives freedom to the interviewee to talk about the problem under the investigation. The researcher also conducts observation to know English learning activity better. Rummel (1964) says that it is necessary to study the school life in the normal setting. Then, Koul (1984) states that the observation must be well planned related to some points as follows: the activities or behaviors to be observed, the nature of the groups of the subjects to be observed, the scope of observation-invidual of group, determining the lenght of observation period, deciding about the tools to record activities during the observation. Patton (1990) says that the position of the researcher in the study is an on-looker or non participant (Cheah Lee Hwa, 2008).The data are mainly about how English teachers in MTsN Selorejo, Blitar employ variety of English learning sources and implement English learning activity that is relevant to students' talent and learning preference.

\section{DISCUSSION OF FINDINGS}

The study was conducted in MTsN Selorejo Blitar in the end of 2014. All English teachers of this school were included as the respondent of the research. The data were gained from interview on the topic of how the teachers employ variety of sources to manage learning activity in line with students' talent and preference to improve students' motivation and achievement in English learning. The data were classified and analyzed according to each activity in English learning. In light of this, English teachers of MTsN Selorejo, Blitar were asked to tell about their experiences to employ variety of sources in particular mass media to promote the students' interest and improve their achievement in English learning.

At present, most of Indonesian schools still apply curriculum 2006 as the guideline to conduct teaching activity to achieve the educational goal. In light of this, English teachers in MTsN Selorejo, Blitar describe that the school still implements curriculum 2006 to conduct English learning activity. It happens not only to MTsN Selorejo but also most of schools in the region of Blitar now. Very few schools in Blitar region already implement curriculum 2013 now. Then, few teachers in Blitar region already joined with in-service training program to implement curriculum 2013 in learning activity well.

As the guideline of English learning activity in MTsN Selorejo, Blitar, it is 
understood that curriculum 2006 emphasizes communicative competence as the educational target in English learning. The students are supposed to have competence to use English as a means of communication with others, improving their knowledge, and advancing science and technology. The curriculum is intended to facilitate the students use English language as a means to express their idea both written and spoken aspect, not merely study the science of English language.

In fact, English teachers of MTsN Selorejo, Blitar absolutely agree that it isn't easy to achieve the goal of English learning: students' communicative competence in written and spoken aspect since the school is located in remote area where students are very limited to expose to English within and outside the school. The situation even bitter than the people imagine since other serious problems also influence learning activity within the school such as student input, student economic status, the awareness of parents on the importance of education, social interaction outside the school and other serious problems. However, the teachers are optimistic to face the situation and always seek some various alternatives to tackle the learning problem in order to create joyful and conducive atmosphere of English learning within the school. The teachers are also aware that each student has his own learning strategy to master the school subject. In light of this, English teachers do very hard to employ variety English learning sources that are easily to access to make English learning run better and students achieve the optimum target of English learning. It is also intended to enrich English learning material for the students. Students have big chance to improve their knowledge and skill form many different learning sources, not merely English textbook published by the government. In light of this, English teachers employ English learning sources that are familiar to the students and easy to access like radio, television, magazine, and newspaper. The teachers ask the students to find some materials related to theme like sport, family, environment, food, and others provided in English corner or English program of mass media. Then, the teachers ask the students to do some activities based on the materials they get from mass media like story telling, writing, and clipping.

\section{a. Story Telling}

In this activity, the teachers ask the students to find some materials from mass media both electronic and printed media related to theme like sport, family, school, market, food. Then, the teachers guide the students to retell the topic with their own words. The students describe the topic with their own simple words so that other students are able to get the points better. The teachers correct their pronunciation and punctuation while they are doing story telling. The teachers often give opportunities to the students to join story telling contest organized by Dinas Pendidikan and other institutions. Some students of this school successfully won the contest. The next, the teachers also guide the students to make short and simple conversation based on topic they get from mass media. The teacher divides the students into some groups. The teacher asks one student to describe the topic in simple words and other students have chance to ask simple question on topic they discuss. This activity makes joyful and conducive atmosphere of English learning activity and facilitates the students who are better at oral fluency to practice more in English oral fluency.

\section{b. Writing}

In this activity, the teachers ask the students to find some topics from mass media to improve their writing proficiency. In this case, the teacher uses both printed and electronic media to design learning materials to improve students' writing skill. The teacher asks the students to summarize short articles or news with their own simple words. Then, the teacher also asks the students to develop short paragraph based on the topic they get from mass media. In this case, the students practice to analyze something and express their own idea in English. The teachers also ask the students to find some new vocabulary from the material of mass media so that vocabulary improvement can be achieved better through many variants of materials not only English textbook. The teachers often sent the students to join writing contest organized by Dinas Pendidikan, Kantor Kementerian Agama, and other institutions. Here, the teachers facilitate the students who are better at writing skill to practice more through writing activity. And, the results showed that 
some students of this school successfully won the contest.

c. Clipping

In this activity, the teachers ask the student to make clipping on some interesting topics related to sport, family, food, and others from printed media. The teachers ask the students to give simple comment on the topics they clip from mass media. The teachers also ask the students to find some new vocabulary and describe the meaning of new vocabulary in simple words. The students usually exhibit their clipping on school magazine or majalah dinding sekolah. Clipping activity is able to promote student's skill in writing. This activity stimulates the students to be creative and more interested in learning English. This activity also provides big latitude to the students to choose or define the topic they like very much to study. Therefore, the students feel more motivated to learn English. The school also often arranges the school magazine contest among classes. Thus, what English teachers and the school did to the students is able to create joyful English learning activity within the school.

\section{CONCLUSION}

English teaching activity cannot depend merely on the English textbook and the material provided by the government. English teachers must be creative and more motivated to use many various learning materials to improve English proficiency among the students. In this modern era, the teachers and the students are easy to access mass media to enrich the material for English learning. Both electronic and printed mass media give big chance to anyone to improve their knowledge in any fields especially English. Mass media facilitates the students develop the language skills, in particular electronic media such as radio and television facilitates the students understand English pronunciation and pronounce English words better. The English teachers in MTsN Selorejo, Blitar are active to use mass media such as newspaper, magazine, radio, and television to enrich the material of English learning for their students. The findings show that teachers guide and teach the students to do oral fluency and writing activity better using the material from mass media. The findings also indicate that the teachers design teaching material and manage teaching activity in line with students' learning preference and talent. It can create joyful learning activities and promote student's interest in English learning. This activity is able to promote students' interest and proficiency in English learning. This activity is also effective to prevent students from using mass media for bad activities like pornography, gossiping, and others. Thus, it can be inferred from the data that English learning activity using the materials from mass media is able to improve students' motivation and achievement of English learning in MTsN Selorejo, Blitar.

\section{REFERENCE}

Azra, A. (2000). The Islamic factor in post-Soeharto Indonesia. In C. Manning \& P. V. Diermen (Eds.), Indonesia in transition: Social aspects of reformasi and crisis (pp. 309-318). Singapore: Institute of Southeast Asian Studies.

Abdul Aziz. (2011). Curriculum Development in Indonesian Education. Jurnal Madrasah Vol. 3 No. 2 2011 pp. $249-264$

Adachi et al, . (1998). Perceptions of the JET Programme, Hiroshima, Keisuisha.

Ali Saukah (2005). English Research Method, Malang, UIN MMI Malang.

Amano Ikuo (1983) Education and Examination in Japan, Tokyo, University of Tokyo Press.

Baker, T.L.(1994). Doing Social Research, New york, McGraw-Hill. 
Brannen,J. (2005). Mixing Methods: The Entry of Qualitative adn Quantitative Approaches into the Research Process, International Jornal of Sociological Methodology,8,173-184.

Cameron. (2001). Teaching Languages to Young Learners, Cambridge, Cambridge University Press.

Cheah Lee Hwa. (2008). The Impact of Principal's Transformational Democratic Leadership Style on Teachers' Job Satisfaction and Commitment, Universiti Sains Malaysia, Thesis.

Marsh, C. and Morris, P. (1991). Curriculum Development in East Asia, London, Falmer Press.

Creswell, J. (2003). Research Design: Qualitative, Quantitative, and Mixed Methods Approaches(2nd edition), Thousand Oaks, CA:Sage.

Cummings, w. (1980). Education and Equality in Japan, New Jersey, Princenton University Press.

Brown, D. (1987). Priciples of Language Learning and Teaching, New Jersey, Prentice-Hall, Inc.

Fairchild, H. (1944). Dictionary of Sociology, New York, Philosophical Library.

Fletcher, P. (1985). A Child's Learning of English, Oxford, Basil Blackwell Publisher.

Hamid Hasan. (2015). Evaluasi Kurikulum, Bandung, Remaja Rosdakarya.

Johnson, R. (1989).The Second Language Curriculum, Cambridge University Press, Cambridge.

Kasihani. (2004). Pengajaran Bahasa Inggris di Sekolah Dasar (English Teaching in Elementary School), Malang, Universitas Negeri Malang.

Katayama et al, (1985,).Readings on Teaching English as a Foreign Language, Tokyo, Daishukan.

Keenleyside and Thomas. (1937).History of Japanese Education, Tokyo, The Hokuseido Press.

Koike Ikuo et al. (1978).The Teaching of English in Japan, Tokyo, Eichosha Publishing.

Koul, L.(1984). Methodology of Educational Research, New Delhi, Vikas Publishing House PVT LTD.

Krejcie, R. V., \& Morgan, D. W. (1970). Determining sample size for research activities. Educational and Psychological Measurement (30), 607-610.

Lado, R. (1961). Language Testing, London, Longman.

Littlewood, W. (1981). Communicative Language Teaching, Cambridge, Cambridge University Press.

Masduki. (1998). Comparing and Contrasting the Teaching of Reading at Junior High School in Indonesia and Japan, Tottori University (Thesis).

Muhaimin et al. (2001). Paradigma Pendidikan Islam (Islamic Education Paradigm), Bandung, Rosdakarya.

Nasution, S. (1986). Didaktik Azas-Azas Mengajar, Jemmars, Bandung.

Okano and Tsuchiya. (1999). Education in Contemporary Japan, Cambridge, Cambridge University Press.

Richards et al. (1997). Dictionary of Language Teaching and Applied Linguistics, Longman Group. 
Rymes, B. (2008). The Relationship between Mass Media and Discourse, Journal of WPEL Vol. 23 No. 12008 pp. 65-88

Schramm, W. (1984) Media Besar Media Kecil (terjemah oleh Agafur), Semarang, IKIP Semarang.

Supeno. (1976). Pendidikan Non Formal dalam Program-Programnya dalam-Pembangunan, Yogyakarta, IKIP Yogyakarta.

Tanner and Tanner. (1980). Curriculum Development, New York, MacMillan Publishing.

Tavani, V. (2009). Teaching Englsih through Mass Media, Journal of Acta Didactica Napocensia Vol. 2 No. 12009 pp.81-97

Tondowidjojo. (1985). Media Masa dan Pendidikan, Jakarta, Gramedia.

Trends in Foreign Second Language Education in Asia and the Pacific, National Institute for Educational Research of Tokyo, 2002. 